\title{
TWENTY-FOURTH ANNUAL LIST OF PAPERS
}

\author{
READ BEFORE THE AMERICAN MATHEMATICAL SOCIETY AND \\ SUBSEQUENTLY PUBLISHED, INCLUDING REFERENCES \\ TO THE PLACES OF THEIR PUBLICATION.
}

Alexander, J. W., II. A proof of the invariance of certain constants of analysis situs. Read Sept. 8, 1913. Transactions of the American Mathematical Society, vol. 16, No. 2, pp. 148-154; April, 1915.

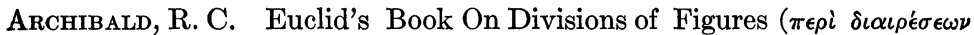
$\left.\beta \iota \beta \lambda_{i o \nu}\right)$ with a restoration based on Woepcke's text and the Practica Geometriæ of Leonardo Pisano. Read April 25, 1914. Cambridge, University Press, 1915 . $8+88 \mathrm{pp}$.

Barus, C. The mathematician in modern physics. Read Sept. 8, 1914. Science, new ser., vol. 40, No. 1038, pp. 721-727; Nov. 20, 1914.

Bateman, H. The quartic curve and its inscribed configurations. Read Feb. 22, 1913. American Journal of Mathematics, vol. 36, No. 4, pp. 357-386; Oct., 1914.

The structure of the æther. Read Feb. 28, 1914. Bulletin of the American Mathematical Sociely, vol. 21, No. 6, pp. 299-309; March, 1915.

The mathematical analysis of electrical and optical wave-motion on the basis of Maxwell's equations. Read (Chicago) April 29, 1911 and Feb. 22, 1913. Cambridge, University Press, 1915. 6+159 pp.

Bauer, G. N., and Slobin, H. L. Algebraic and transcendental numbers. Read (Chicago) Dec. 27, 1913. Rendiconti del Circolo Matematico di Palermo, vol. 38, No. 3, pp. 353-356; Nov.-Dec., 1914.

BeLL, E. T. An arithmetical theory of certain numerical functions. Part 1. Read Oct. 26, 1912 and (San Francisco) May 22, 1914. University of Washington Publications (Science), 1915. $47 \mathrm{pp}$.

Bernstein, B. A. A complete set of postulates for the logic of classes expressed in terms of the operation "exception," and a proof of the independence of a set of postulates due to Del Ré. Read (San Francisco) Oct. 25, 1913. University of California Publications in Mathematics, vol. 1, No. 4, pp. 87-96; May 15, 1914.

Birkнoff, G. D. An elementary double inequality for the roots of an algebraic equation having greatest absolute value. Read April 24, 1915. Bulletin of the American Mathematical Society, vol. 21, No. 10, pp. 494-495; July, 1915.

Blichfeldt, H. F. A new principle in the geometry of numbers, with some applications. Read (San Francisco) April 12, 1913. Transactions of the American Mathematical Society, vol. 15, No. 3, pp. 227235; July, 1914.

Bliss, G. A. A note on symmetric matrices. Read (Chicago) April 10, 1914. Annals of Mathematics, ser. 2, vol. 16, No. 1, pp. 43-44; Sept., 1914.

The Weierstrass $E$-function for problems of the calculus of variations in space. Read (Chicago) Dec. 26, 1913. Transactions of the American Mathematical Society, vol. 15, No. 4, pp. 369-378; Oct., 1914. 
- Generalizations of geodesic curvature and a theorem of Gauss concerning geodesic triangles. Read April 28, 1906. American Journal of Mathematics, vol. 37, No. 1, pp. 1-18; Jan., 1915.

- A note on functions of lines. Read (Chicago) Dec. 28, 1914. Proceedings of the National Academy of Sciences, vol. 1, No. 3, pp. 173-177; March, 1915.

Bliss, G. A., and UNDerHiLl, A. L. The minimum of a definite integral for unilateral variations in space. Read (Chicago) Dec. 27, 1913. Transactions of the American Mathematical Society, vol. 15, No. 3, pp. 291-310; July, 1914.

Bôcher, M. On a small variation which renders a linear differential system incompatible. Read April 25, 1914. Bulletin of the American Mathematical Society, vol. 21, No. 1, pp. 1-6; Oct., 1914.

- The smallest characteristic numbers in a certain exceptional case. Read Sept. 8, 1914. Bulletin of the American Mathematical Society, vol. 21, No. 1, pp. 6-9; Oct., 1914.

Buchanan, D. Periodic orbits on a smooth surface. Read (Chicago) Dec. 26, 1913. American Journal of Mathematics, vol. 37 No. 1, pp. 79-94; Jan., 1915.

Burns, J. E. The abstract definitions of groups of degree 8. Read Sept. 8, 1913. American Journal of Mathematics, vol. 37, No. 2, pp. 195214; April, 1915.

CaJori, F. The history of Zeno's arguments on motion: phases in the development of the theory of limits. Read Sept. 9, 1913 and (Chicago) April 11, 1914. American Mathematical Monthly, vol. 22, No. 1, pp. 1-6; Jan., 1915: No. 2, pp. 39-47; Feb., 1915: No. 3, pp. 77-82; March, 1915: No. 4, pp. 109-115; April, 1915.

Carmichael, R. D. On series of iterated linear fractional functions. Read Sept. 8, 1913. American Journal of Mathematics, vol. 36, No. 3, pp. 267-288; July, 1914.

Carmichael, R. D., and Mason, T. E. Note on the roots of algebraic equations. Read (Chicago) April 10, 1914. Bulletin of the American Mathematical Society, vol. 21, No. 1, pp. 14-22; Oct., 1914.

Chittenden, E. W. The converse of the Heine-Borel theorem in a Riesz domain. Read (Chicago) April 11, 1914. Bulletin of the American Mathematical Society, vol. 21, No. 4, pp. 179-183; Jan., 1915.

- Infinite developments and the composition property $\left(K_{12} B_{1}\right)$ in general analysis. Read (Chicago) April 6, 1912. Rendioonti del Circolo Matematico di Palermo, vol. 39, No. 1, pp. 81-108; Jan.-Feb., 1915.

Coвle, A. B. Restricted systems of equations (second paper). Read Dec. 31, 1913. American Journal of Mathematics, vol. 36, No. 4, pp. 395-418; Oct., 1914.

— Point sets and allied Cremona groups. Read April 25, 1914. Transactions of the American Mathematical Society, vol. 16, No. 2, pp. 155198; April, 1915. Proceedings of the National Academy of Sciences, vol. 1, No. 4, pp. 245-248; April, 1915.

Cole, F. N. Note on solvable quintics. Read Jan. 2, 1915. Bulletin of the American Mathematical Society, vol. 21, No. 9, pp. 462-464; June, 1915. 
Conner, J. R. The rational sextic curve, and the Cayley symmetroid. Read Dec. 31, 1912. American Journal of Mathematics, vol. 37, No. 1, pp. 29-42; Jan., 1915.

Copeland, L. P. On the theory of invariants of $n$-lines. Read Feb. 22, 1913. Annals of Mathematics, ser. 2, vol. 16, No. 1, pp. 7-14; Sept., 1914.

Cummings, L. D. On a method of comparison for triple systems. Read April 25, 1914. Transactions of the American Mathematical Society, vol. 15, No. 3, pp. 311-327; July, 1914.

Craig, C. F. See Sharpe, F. R.

DECKer, F. F. On the order of a restricted system of equations. Read Dec. 28, 1910. American Journal of Mathematics, vol. 37, No. 2, pp. 159-178; April, 1915.

Dickson, L. E. Modular invariants of the system of a binary cubic, quadratic, and linear form. Read Sept. 8, 1914. Quarterly Journal of Pure and Applied Mathematics, vol. 45, No. 4, pp. 373-384; Sept., 1914.

- Invariants in the theory of numbers. Read Sept. 8, 1914. Transactions of the American Mathematical Society, vol. 15, No. 4, pp. 497503; Oct., 1914.

- The points of inflexion of a plane cubic curve. Read Sept. 8, 1914. Annals of Mathematics, ser. 2, vol. 16, No. 2, pp. 50-66; Dec., 1914.

- Linear algebras. Read (Chicago) Dec. 27, 1913. Cambridge Tracts in Mathematics and Mathematical Physics, No. 16. Cambridge, University Press, 1914 . 8+73 pp.

- Invariants, seminvariants, and covariants of the ternary and quaternary quadratic form modulo 2. Read Sept. 8, 1914. Bulletin of the American Mathematical Society, vol. 21, No. 4, pp. 174-179; Jan., 1915. Invariantive theory of plane cubic curves modulo 2. Read (San Francisco) Oct. 24, 1914. American Journal of Mathematics, vol. 37, No. 2, pp. 107-116; April, 1915.

- Quartic curves modulo 2. Read (San Francisco) Oct. 24, 1914. Transactions of the American Mathematical Society, vol. 16, No. 2, pp. 111120; April, 1915.

— The straight lines on modular cubic surfaces. Read (Chicago) Dec. 29, 1914. Proceedings of the National Academy of Sciences, vol. 1, No. 4, pp. 248-253; April, 1915.

- Projective classification of cubic surfaces modulo 2. Read (Chicago) Dec. 29, 1914. Annals of Mathematics, ser. 2, vol. 16, No. 4, pp. 139-157; June, 1915.

Dines, L. L. Complete existential theory of Sheffer's postulates for Boolean algebras. Read Dec. 30, 1913. Bulletin of the American Mathematical Society, vol. 21, No. 4, pp. 183-188; Jan., 1915.

DodD, E. L. The arithmetic mean as approximately the most probable value a posteriori under the Gaussian probability law. Read Sept.9, 1913. Bulletin of the University of Texas, 1915, No. 4, 20 pp.; Jan. 15, 1915.

Dresden, A. The second derivatives of the extremal integral for a general class of problems of the calculus of variations. Read (Chicago) Dec. 28, 1914. Proceedings of the National Academy of Sciences, vol. 1, No. 4, pp. 238-241; April, 1915. 
Eisenhart, L. P. Transformations of surfaces of Voss. Read Dec. 31, 1913. Transactions of the American Mathematical Society, vol. 15, No. 3, pp. 245-265; July, 1914.

Transformations of conjugate systems with equal point invariants. Read April 25, 1914. Transactions of the American Mathematical Society, vol. 15, No. 4, pp. 397-430; Oct., 1914.

Transformations of surfaces $\Omega$. Read Jan. 1, 1915. Proceedings of the National Academy of Sciences, vol. 1, No. 2, pp. 62-65; Feb., 1915.

- One-parameter families of curves. Read (Chicago) April 28, 1911. American Journal of Mathematics, vol. 37, No. 2, pp. 179-191; April, 1915.

Емсн, A. On some properties of closed continuous curves. Read Dec. 31, 1912 and (Chicago) Dec. 28, 1914. Rendiconti del Circolo Matematico di Palermo, vol. 38, No. 2, pp. 180-184; Sept.-Oct., 1914.

- On some general theorems concerning ordinary closed curves. Read (Chicago) Dec. 28, 1914. Annals of Mathematics, ser. 2, vol. 16, No. 4, pp. 193-196; June, 1915.

Evans, G. C. On the reduction of integro-differential equations. Read Jan. 1, 1913 and Dec. 30, 1913. Transactions of the American Mathematical Society, vol. 15, No. 4, pp. 477-496; Oct., 1914.

- Note on the derivative and the variation of a function depending on all the values of another function. Read Jan. 2, 1915. Bulletin of American Mathematical Society, vol. 21, No. 8, pp. 387-397; May, 1915.

Fischer, C. A. The derivative of a function of a surface. Read April 26, 1913. American Journal of Mathematics, vol. 36, No. 3, pp. 289-306; July, 1914.

The Legendre condition for a minimum of a double integral, with an isoperimetric condition. Read Feb. 28, 1914. Bulletin of the American Mathematical Society, vol. 21, No. 8, 380-387; May, 1915.

- Minima of double integrals with respect to one-sided variations. Read April 24, 1915. Annals of Mathematics, ser. 2, vol. 16, No. 4, pp. 162-168; June, 1915.

Fire, W. B. Prime power groups in which every commutator of prime order is invariant. Read Sept. 9, 1914. Transactions of the American Mathematical Society, vol. 16, No. 2, pp. 134-138; April, 1915.

FrIZeLl, A. B. An enumeration of integral algebraic polynomials. Read Jan. 1, 1915. Bulletin of the American Mathematical Society, vol. 21, No. 7, pp. 341-342; April, 1915.

- Certain non-enumerable sets of infinite permutations. Read (Chicago) April 10, 1914 and Dec. 28, 1914. Bulletin of the American Mathematical Society, vol. 21, No. 10, pp. 495-499; July, 1915.

GABA, M. G. A set of postulates for general projective geometry. Read April 26, 1913. Transactions of the American Mathematical Society, vol. 16, No. 1, pp. 51-61; Jan., 1915.

GalaJikian, $\mathrm{H}$. Non-linear integral equations of the Volterra type. Read Dec. 31, 1913. Annals of Mathematics, ser. 2, vol. 16, No. 4, pp. 172-192; June, 1915.

GLenN, O. E. Concerning an analogy between formal modular invariants and the class of algebraical invariants called Booleans. Read Dec. 30, 1913. American Journal of Mathematics, vol. 37, No. 1, pp. 73-78; Jan., 1915. 
- Modular invariant processes. Read Sept. 8, 1914. Bulletin of the American Mathematical Society, vol. 21, No. 4, pp. 167-173; Jan., 1915.

Glover, J. W. A general formula for the valuation of securities. Read (Chicago) April 6, 1912. American Mathematical Monthly, vol. 22, No. 3, pp. 82-88; March, 1915.

Graustein, W. C. The equivalence of complex points, planes, lines with respect to real motions and certain other groups of real transformations. Read Dec. 31, 1913. Transactions of the American Mathematical Society, vol. 16, No. 1, pp. 33-44; Jan., 1915.

Green, G. M. One-parameter families of curves in the plane. Read Oct. 25, 1913. Transactions of the American Mathematical Society, vol. 15, No. 3, pp. 277-290; July, 1914.

- On the theory of curved surfaces, and canonical systems in projective differential geometry. Read Dec. 31, 1913. Transactions of the American Mathematical Society, vol. 16, No. 1, pp. 1-12; Jan., 1915.

Gronwall, T. H. Ueber die Summierbarkeit der Reihen von Laplace und Legendre. Read Jan. 2, 1913. Mathematische Annalen, vol. 75, No. 3, pp. 321-375; July, 1914.

- On approximation by trigonometric sums. Read Dec. 31, 1913. Bulletin of the American Mathematical Society, vol. 21, No. 1, pp. 9-14; Oct., 1914.

- Some remarks on conformal representation. Read Oct. 31, 1914. Annals of Mathematics, ser. 2, vol. 16, No. 2, pp. 72-76; Dec., 1914.

- On the maximum modulus of an analytic function. Read April 26, 1913. Annals of Mathematics, ser. 2, vol. 16, No. 2, pp. 77-81; Dec., 1914.

- An integral equation of the Volterra type. Read Jan. 2, 1915. Annals of Mathematics, ser. 2, vol. 16, No. 3, pp. 119-122; March, 1915.

HazLeTt, O. Invariantive characterization of some linear associative algebras. Read (Chicago) Dec. 26,1913. Annals of Mathematics, ser. 2, vol. 16, No. 1, pp. 1-6; Sept., 1914.

Hildebrandt, T. H. On a generalization of a theorem of Dini on sequences of continuous functions. Read (Chicago) April 10, 1914. Bulletin of the American Mathematical Society, vol. 21, No. 3, pp. 113-115; Dec., 1914.

Howland, L. A. Binary conditions for double and triple points on a cubic. Read April 27, 1912. American Journal of Mathematics, vol. 36, No. 4, pp. 441-448; Oct., 1914.

Huntington, E. V. The theorem of rotation in elementary mechanics. Read Sept. 8, 1914. American Mathematical Monthly, vol. 21, No. 10, pp. 315-320; Dec., 1914.

Hurwitz, W. A. Mixed linear integral equations of the first order. Read Dec. 31, 1912. Transactions of the American Mathematical Society, vol. 16, No. 2, pp. 121-133; April, 1915.

IRwIN, F. Relation between the roots of a rational integral function and its derivative. Read (San Francisco) Oct. 24, 1914. Annals of Mathematics, ser. 2, vol. 16, No. 3, p. 138; March, 1915.

JACKson, D. A formula of trigonometric interpolation. Read Sept. 8, 1913. Rendiconti del Circolo Matematico di Palermo, vol. 37, No. 3, pp. 371-378; May-June, 1914. 
- On the degree of convergence of Sturm-Liouville series. Read Dec. 30, 1913. Transactions of the American Mathematical Society, vol. 15, No. 4, pp. 439-466; Oct., 1914.

Jofre, S. A. Sums of like powers of natural numbers. Read Feb. 24, 1912. Quarterly Journal of Pure and Applied Mathematics, vol. 46, No. 1, pp. 33-51; Dec., 1914.

Johnson, R. A. The conic as a space element. Read Sept. 8, 1914. Transactions of the American Mathematical Society, vol. 15, No. 4, pp. 335-368; Oct., 1914.

KARPINsKI, L. C. The algorism of John Killingworth. Read Sept. 8, 1913. English Historical Review, vol. 29, No. 4, pp. 707-717; Oct., 1914.

KASNER, E. Equitangential congruences of curves in space. Read Feb. 25, 1911 and Jan. 1, 1913. Rendiconti del Circolo Matematico di Palermo, vol. 35, No. 3, pp. 283-285; May-June, 1913.

LAMOND, J. K. On the continuity of a Lebesgue integral with respect to a parameter. Read April 25, 1914. American Journal of Mathematics, vol. 36, No. 4, pp. 387-391; Oct., 1914.

LEFSCHETZ, S. Geometry on ruled surfaces. Read (Southwestern Section) Nov. 30, 1912. American Journal of Mathematics, vol. 36, No. 4, pp. 392-394; Oct., 1914.

- The equation of Picard-Fuchs for an algebraic surface with arbitrary singularities. Read (Southwestern Section) Nov. 28, 1914. Bulletin of the American Mathematical Society, vol. 21, No. 5, pp. 227-232; Feb., 1915.

Lehmer, D. N. List of prime numbers from 1 to 10,006,721. Read (San Francisco) Feb. 26, 1910. Carnegie Institution Publication No. 165. Washington, 1914 . $16+133 \mathrm{pp}$.

LONGLFY, W. R. An existence theorem for a certain differential equation of the $n$th order. Read Dec. 30, 1913. Transactions of the American Mathematical Society, vol. 15, No. 3, pp. 328-334; July, 1914.

Love, C. E. Singular integral equations of the Volterra type. Read Sept. 8, 1914. Transactions of the American Mathematical Society, vol. 15, No. 4, pp. 467-476; Oct., 1914.

Lytle, E. B. Proper multiple integrals over iterable fields. Read Sept. 8, 1913. Transactions of the American Mathematical Society, vol. 15, No. 4, pp. 504-505; Oct., 1914.

MacMillan, W. D. On Foucault's pendulum. Read (Chicago) Dec. 26, 1913. American Journal of Mathematics, vol. 37, No. 1, pp. 95-106; Jan., 1915.

ManNing, W. A. On the order of primitive groups, II. Read (San Francisco) Feb. 27, 1909. Transactions of the American Mathematical Society, vol. 16, No. 2, pp. 139-147; April, 1915.

Marshald, W. Die Funktionen des parabolischen Zylinders. Read Sept. 8, 1913. Archiv der Mathematik und Physik, ser. 3, vol. 23, No. 4, pp. 324-338; March, 1915.

Mason, T. E. On some properties of the elementary symmetric functions of the integers 1, 2, $\cdots, n-1$. Read (Chicago) April 10, 1914. Tôhoku Mathematical Journal, vol. 5, Nos. 3-4, pp. 136-141; June, 1914. 
Character of the solutions of certain functional equations. Read Sept. 8, 1913. American Journal of Mathematics, vol. 36, No. 4, pp. 419-440; Oct., 1914.

See Carmichael, R. D.

Miller, G. A. Note on multiply transitive solvable substitution groups. Read (Chicago) April 10, 1914. Archiv der Mathematik und Physik, ser. 3, vol. 23, No. 1, pp. 32-33; June, 1914.

— The $\phi$-subgroup of a group. Read Sept. 8, 1914. Transactions of the American Mathematical Society, vol. 16, No. 1, pp. 20-26; Jan., 1915. Proceedings of the National Academy of Sciences, vol. 1, No. 1, pp. 6-7; Jan., 1915.

- Note on the potential and the antipotential group of a given group. Read (Chicago) Dec. 29, 1914. Bulletin of the American Mathematical Society, vol. 21, No. 5, pp. 221-227; Feb., 1915.

- Groups possessing at least one set of independent generators composed of as many operators as there are prime factors in the order of the group. Read (Chicago) April 3, 1915. Proceedings of the National Academy of Sciences, vol. 1, No. 4, pp. 241-244; April, 1915.

- A new proof of Sylow's theorem. Read (Chicago) Dec. 29, 1914. Annals of Mathematics, ser. 2, vol. 16, No. 4, pp. 169-171; June, 1915.

MitcheLl, H. H. The subgroups of the quaternary abelian linear group. Read April 25, 1914. Transactions of the American Mathematical Society, vol. 15, No. 4, pp. 379-396; Oct., 1914.

Moore, C. L. E. Note on normal sections of a surface in a space of $n$ dimensions. Read April 25, 1914. Annals of Mathematics, ser. 2, vol. 16, No. 3, pp. 89-96; March, 1915.

- Geometry whose element of arc is a linear differential form, with application to the study of minimum developables. Read April 25, 1914. Proceedings of the American Academy of Arts and Sciences, vol. 50, No. 9, pp. 197-222; June, 1915.

Moore, C. N. Sur la relation entre certaines méthodes pour la sommation d'une série divergente. Read (Chicago) April 10, 1914. Comptes Rendus de l'Académie des Sciences, vol. 158, No. 24, pp. 1774-1775; June 15, 1914.

Moore, R. L. On a set of postulates which suffice to define a numberplane. Read April 27, 1912. Transactions of the American Mathematical Society, vol. 16, No. 1, pp. 27-32; Jan., 1915.

- The linear continuum in terms of point and limit. Read April 25, 1914. Annals of Mathematics, ser. 2, vol. 16, No. 3, pp. 123-133; March, 1915.

Morgan, F. M. A plane cubic Cremona transformation and its inverse. Read Sept. 8, 1914. Annals of Mathematics, ser. 2, vol. 16, No. 3, pp. 134-137; March, 1915.

Moutton, F. R. Solution of an infinite system of differential equations of the analytic type. Read (Chicago) April 2, 1915. Proceedings of the National Academy of Sciences, vol. 1, No. 6, pp. 350-354; June, 1915.

Pell, A. J. Non-homogeneous linear equations in infinitely many unknowns. Read April 25, 1914. Annals of Mathematics, ser. 2, vol. 16, No. 1, pp. 32-37; Sept., 1914. 
Pitcher, A. D. On the connection of an abstract set, with applications to the theory of functions of a general variable. Read April 26, 1913. American Journal of Mathematics, vol. 36, No. 3, pp. 261-266; July, 1914.

Putnam, T. M. Residues of certain sums of powers of integers. Read (San Francisco) April 26, 1913. American Mathematical Monthly, vol. 21, No. 7, pp. 220-222; Sept., 1914.

RANUm, A. On the differential geometry of ruled surfaces in 4-space and cyclic surfaces in 3-space. Read Jan. 1, 1915. Transactions of the American Mathematical Society, vol. 16, No. 1, pp. 89-110; Jan., 1915.

- On the projective differential classification of $n$-dimensional spreads generated by $\infty^{1}$ flats. Read Jan. 1, 1913. American Journal of Mathematics, vol. 37, No. 2, pp. 117-158; April, 1915.

Robinson, L. B. Sur les systèmes d'équations aux dérivées partielles. Read Feb. 22, 1913. Comptes Rendus de l'Académie des Sciences, vol. 157, No. 2, pp. 106-108; July 15, 1913.

Roever, W. H. Deviations of falling bodies. Read Feb. 28, 1914. Astronomical Journal, vol. 28, Nos. 22-24, pp. 177-201, Part II; Jan. $22,1915$.

- A geometric derivation of a general formula for the southerly deviation of freely falling bodies. Read Oct. 25, 1913. Bulletin of the American Mathematical Society, vol. 21, No. 9, pp. 444-462; June, 1915.

RowE, J. E. Invariants of the rational plane quintic curve and of any rational curve of odd order. Read April 25,1914. Transactions of the American Mathematical Society, vol. 16, No. 1, pp. 45-50; Jan., 1915.

SAFFoRd, F. H. An irrational transformation of the Weierstrass $\wp_{\text {-function }}$ curves. Read Sept. 10, 1912. Archiv der Mathematik und Physik, ser. 3, vol. 23, No. 1, pp. 10-14; June, 1914.

Schweitzer, A. R. Remarks on functional equations. Read Sept. 8, 1913. Bulletin of the American Mathematical Society, vol. 21, No. 1, pp. 23-29; Oct., 1914.

Seely, C. E. Certain non-linear integral equations. Read Jan. 1, 1915. Author's dissertation. Lancaster, 1914. $32 \mathrm{pp}$.

Sharpe, F. R. Finite groups of plane birational transformations with eight fundamental points. Read Dec. 27, 1911 and Sept. 10, 1912. American Journal of Mathematics, vol. 37, No. 1, pp. 55-64; Jan., 1915.

- Conics through inflections of self-projective quartics. Read Sept. 10, 1912 and Sept. 9, 1913. American Journal of Mathematics, vol. 37, No. 1, pp. 65-72; Jan., 1915.

Sharpe, F. R. and Craig, C. F. An application of Severi's theory of a basis to the Kummer and Weddle surfaces. Read Feb. 28, 1914. Transactions of the American Mathematical Society, vol. 15, No. 3, pp. 236-244; July, 1914.

Plane curves with consecutive double points. Read Sept. 9, 1913. Annals of Mathematics, ser. 2, vol. 16, No. 1, pp. 15-21; Sept., 1914. 
Sharpe, F. R. and Snyder, V. Birational transformations of certain quartic surfaces. Read Feb. 28, 1914. Transactions of the American Mathematical Society, vol. 15, No. 3, pp. 266-276; July, 1914.

- See SNYder, V.

Slepian, J. The functions of a complex variable defined by an ordinary differential equation of the first order and the first degree. Read April 26, 1913. Transactions of the American Mathematical Society, vol. 16, No. 1, pp. 71-88; Jan., 1915.

Slobin, H. L. See Bauer, G. N.

SNYDER, V. Birational transformations of the cubic variety in fourdimensional space. Read Dec. 30, 1913. Rendiconti del Circolo Matematico di Palermo, vol. 38, No. 3, pp. 344-352; Nov.-Dec., 1914.

SNYder, V. and Sharpe, F. R. Certain quartic surfaces belonging to infinite discontinuous cremonian groups. Read Jan. 1, 1915. Transactions of the American Mathematical Society, vol. 16, No. 1, pp. 62-70; Jan., 1915.

- See Sharpe, F. R.

Sullivan, C. T. Scroll directrix curves. Read (Chicago) Dec. 27, 1913. Transactions of the Amercan Mathematical Society, vol. 16, No. 2, pp. 199-214; April, 1915.

Underhill, A. L. See Bliss, G. A.

VANDIVER, H. S. Extension of the criteria of Wieferich and Mirimanoff in connection with Fermat's last theorem. Read April 25, 1914. Journal für die reine und angewandte Mathematik, vol. 144, No. 4, pp. 314-318; July, 1914.

VAN Vleck, E. B. The rôle of the point-set theory in geometry and dynamics. Read Jan. 1, 1915. Bulletin of the American Mathematical Society, vol. 21, No. 7, pp. 321-341; April, 1915.

Wahlin, G. E. The equation $x^{l}-A=0(p)$. Read (Chicago) Dec. 27, 1913. Journal für die reine und angewandte Mathematik, vol. 145, Nos. 1-3, pp. 114-138; Nov., 1914-March, 1915.

Webster, A. G. Henri Poincaré as a mathematical physicist. Read Dec. 31, 1912. Science, new ser., vol. 38, No. 991, pp. 901-909; Dec. $26,1913$.

Westfall, W. D. A. Continuity of functions of infinitely many variables. Read (Southwestern Section) Nov. 27, 1909. Rendiconti del Circolo Matematico di Palermo, vol. 39, No. 1, pp. 74-80; Jan.-Feb., 1915.

White, H. S. The multitude of triad systems on 31 letters. Read Sept. 8, 1914. Transactions of the American Mathematical Society, vol. 16, No. 1, pp. 13-19; Jan., 1915. Proceedings of the National Academy of Sciences, vol. 1, No. 1, pp. 4-5; Jan., 1915.

WILCZYNski, E. J. On a certain completely integrable system of linear partial differential equations. Read Jan. 1, 1913. American Journal of Mathematics, vol. 36, No. 3, pp. 231-260; July, 1914.

- Ueber Flächen mit unbestimmten Direktrixkurven. Read Sept. 9, 1913 and (Chicago) Dec. 26, 1913. Mathematische Annalen, vol. 76, No. 1, pp. 129-160; Dec., 1914.

- Conjugate systems of space curves with equal Laplace-Darboux invariants. Read (Chicago) Dec. 28, 1914. Proceedings of the National Academy of Sciences, vol. 1, No. 2, pp. 59-61; Feb., 1915. 
Wiley, F. B. Proof of the finiteness of the modular covariants of a system of binary forms and cogredient points. Read Sept. 8, 1914. Transactions of the American Mathematical Society, vol. 15, No. 4, pp. 431438; Oct., 1914.

Williams, K. P. Concerning a certain totally discontinuous function. Read Oct. 31, 1914. Bulletin of the American Mathematical Society, vol. 21, No. 3, pp. 117-120; Dec., 1914.

Wilson, E. B. Infinite regions in geometry. Read Feb. 28, 1914. Bulletin of the American Mathematical Society, vol. 21, No.2, pp. 73-82; Nov., 1914.

- Discussion of the Ziwet-Field "Note on plane kinematics." Read Feb. 27, 1915. American Mathematical Monthly, vol. 22, No. 4, pp. 121-124; April, 1915. 